\title{
Dziady cz. IV w zwierciadle ekosystemu romantycznego
}

\section{Dziady part. IV in the mirror of the romantic ecosystem}

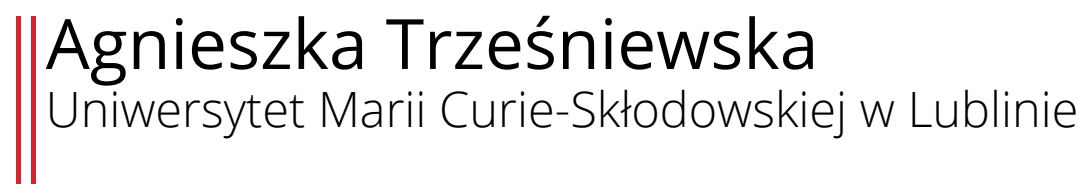

\begin{abstract}
In this article, I have used the metaphor of the ecosystem in which animals, plants and humans are involved. Animals play an important role in the Mickiewicz's ecosystem, becoming the basis for revaluing the thought of who can be a hero, because the author recognizes them as equal with those of Gustav or Priest figure. What is more, animals are not being perceived as objects any more. Mickiewicz's hero sees himself as part of nature. In the article special attention has been paid to the insects as animals standing at the crossroads of life and death. In this role, the author of Dziady part IV casted insects, which seem to blur the boundary between two realities.
\end{abstract}

Key words: ecosystem, insects, ecocriticism, animal studies

Streszczenie: W artykule, poświęconym czwartej części Dziadów Adama Mickiewicza, posłużyłam się metaforą ekosystemu, w który uwikłane są zwierzęta, rośliny oraz ludzie. Zwierzęta odgrywają istotną rolę w Mickiewiczowskim ekosystemie, stając się podstawą przewartościowania myślenia o tym, kto może być bohaterem, gdyż autor przyznaje im status równoprawny z tym, który posiadają Gustaw czy Ksiądz. Co więcej, zwierzęta przestają być postrzegane przedmiotowo. Mickiewiczowski bohater widzi siebie jako cząstkę natury. W artykule zwrócono szczególną uwagę na insekty jako zwierzęta stojące na styku śmierci i życia. W tej roli autor Dziadów obsadził owady, które zdają się zacierać granicę między dwoma rzeczywistościami.

Słowa kluczowe: ekosystem, ekokrytyka, Mickiewicz, owady

Nie ulega wątpliwości, iż romantyzm polski, zrywając z sentymentalnym wizerunkiem natury, zmienił sposób mówienia oraz pisania o przyrodzie, gdyż przestała ona pełnić funkcję dekoracyjną w utworze. Romantycy odkryli nowy wymiar uniwersum, w którym natura ${ }^{1}$ nie była już bierna, pasywna, lecz stała się niezwykle dynamiczna, niekiedy mroczna, czasami

${ }^{1}$ Zamienność stosowania terminów: natura, przyroda, biosfera przejmuję od Zdzisławy Piątek, która twierdzi, iż termin przyroda rozumiany jest przez nią „w sensie scholastycznym jako oznaczająca Natura - rodzicielka”, odnoszony także będzie on do dzikiej przyrody ożywionej. Wyjaśniając stwórcze rozumienie przyrody, badaczka odwołuje się „do naturalnych mechanizmów zmienności i doboru naturalnego, opisywanych przez teorię ewolucji. Będzie to zatem spojrzenie na przyrodę 
wręcz zagrażająca człowiekowi. Wspomnijmy choćby balladę Lilie Adama Mickiewicza czy Balladynę Juliusza Słowackiego, w których to utworach natura staje się równoprawnym bohaterem, ingerującym w egzystencję ludzką, wymierzając karę osobom postępującym niemoralnie. Tak przedstawiona wizja natury musi zawierać elementy spojrzenia antropocentrycznego, gdyż niemożliwe jest całkowite porzucenie ludzkiego spojrzenia na biosferę (Piątek 1998, 12).

Zmiany w postrzeganiu przyrody odzwierciedla także malarstwo romantyczne ${ }^{2}$. Przywołajmy choćby obraz Kredowe skały Rugii (1818) Caspara Davida Friedricha, którego głównym bohaterem, jak wskazuje tytuł, staje się natura zawsze towarzysząca człowiekowi. Skały, drzewa, morze oraz niebo okazują się nie tylko źródłem kontemplacji (poszukiwania Boga), ale również podkreślają potęgę ekosystemu. W obliczu skalistego, białego wybrzeża człowiek wydaje się istotą niezwykle kruchą. Płótno Friedricha eksponuje statyczny obraz przyrody, co potęgują pastelowe barwy (podkreślające dystans między człowiekiem a naturą), ale jednocześnie budzi pewnego rodzaju niepokój, wynikający z faktu, iż jednostka staje się bezbronna wobec praw natury. Drugi niezwykle popularny wizerunek przyrody, ukazujący ją jako twór dynamiczny, pojawia się w malarstwie Williama Turnera. Na obrazie Burza śnieżna - Parowiec przed wejściem do portu (1842) malarz przedstawia realia morskiej burzy, eksponując wzburzone fale i gwałtowne podmuchy wiatru za pomocą zaokrąglonych linii, podkreślających kolistą strukturę kompozycji. Natura staje się nieokiełznanym żywiołem, w konfrontacji z którym człowiek skazany jest na klęskę. Nawiasem mówiąc, obraz ten koresponduje z sonetem Burza Adama Mickiewicza.

Trudno wskazać romantyczny utwór, w którym nie pojawia się natura. Wydajesię,iżegzystencjaromantykówjestściślesplecionazeświatemprzyrody ukazywanym zarówno podmiotowo, jak i przedmiotowo. Antropocentryczne spojrzenie na biosferę ma swoje uzasadnienie, gdyż całkowite jego porzucenie jest nie tylko trudne, ale czasami wręcz niemożliwe. Zgodnie z twierdzeniem Zdzisławy Piątek, antropocentryzm to „ludzki sposób doświadczania świata" (Piątek 1998, 12), który nie powinien być odrzucany.

W niniejszym artykule pragnę spojrzeć na relacje człowiek - natura w literaturze I połowy XIX wieku z perspektywy ekokrytycznej, w której antropocentrycznemu spojrzeniu towarzyszyć będzie krytyka szowinizmu gatunkowego ${ }^{3}$. Postaram się odpowiedzieć na pytania: jaką rolę pełni ekosystem Dziadów cz. IV Adama Mickiewicza?; gdzie w tym ekosystemie

jako źródło wartości z punktu widzenia teorii ewolucji i będzie ono uzasadnione o tyle, o ile ta teoria jest uzasadniona" (Piątek 1993, 159).

2 Należy zaznaczyć, iż romantyzm polski różni się znacząco pod względem przedstawiania przyrody od romantyzmu angielskiego, dlatego dla całościowego obrazu ważne jest przywołanie malarstwa anglosaskiego jako kontekstu. Szerszej problem recepcji ekokrytyki na gruncie polskim i anglosaskim porusza Anna Barcz (Barcz 2016, 49).

3 Szowinizm gatunkowy, inaczej zwany jest gatunkowizmem, to jedno z podstawowych pojęć współczesnego ruchu praw zwierząt. Polega on na traktowaniu podrzędnie innych gatunków niż homo sapiens. Termin ten upowszechnił Peter Singer w swojej książce Wyzwolenie zwierząt. Więcej na ten temat (Stanisławski, 2015). 
znajduje się człowiek? Użycie narzędzi ekokrytycznych pozwoli na nowe odczytanie utworu Mickiewicza, który w szkolnych interpretacjach funkcjonuje jako historia nieszczęśliwej miłości Gustawa i Maryli.

$\mathrm{Na}$ początku zaznaczę, iż posługiwać się będę nomenklaturą ekokrytyczną, postrzegając ekosystem jako przestrzeń współtworzoną przez świat roślin, zwierząt, w którą wpisana jest również egzystencja człowieka ${ }^{4}$. Jak zauważa Julia Fiedorczuk, początki ekokrytyki (były to lata 70. i 80. ubiegłego wieku) opierały się przede wszystkim na tekstach literackich, w których „pozaludzka przyroda stanowi kwestię absolutnie pierwszoplanową” (Fiedorczuk 2015, 21). Niemniej jednak współczesna ekokrytyka koncentruje się na sytuowaniu wobec siebie poszczególnych elementów ekosfery, stawiając pytania o bliskość i oddalenie ich wobec natury (Barcz 2012, 59). Relacje wspomnianych elementów biosfery są ściśle ze sobą powiązane, co niezwykle trafnie oddaje współczesna metafora splątanych sieci, zaproponowana przez Ewę Domańską (Domańska 2013, 27). Aby pokazać szereg zależności zachodzących między bohaterem Mickiewiczowskim a otaczającym go światem, warto skorzystać z szerszej perspektywy badawczej, jaką bez wątpienia jest ekokrytyka ${ }^{5}$.

W dramacie Mickiewicza (podobnie jak w innych utworach romantycznych) odnaleźć możemy postpastoralną ${ }^{6}$ koncepcję natury, w której przyroda staje się równoprawnym bohaterem; nie wydaje się ona jednoznaczna, gdyż nie jest już tożsama z ostoją ładu i spokoju (są to cechy charakterystyczne dla pastoralnej wizji świata natury), ale także nie symbolizuje chaosu i zła, a czasem naiwności oraz hipokryzji (cech typowych dla antypastoralnej wizji przyrody) (Tabaszewska 2011, 218). Świat natury łączy w sobie elementy kreacyjne, tak charakterystyczne dla pastoralizmu, $\mathrm{z}$ elementami destrukcyjnymi, widocznymi w antypastoralnych obrazach natury. Odzwierciedla to między innymi więzi łączące człowieka przechodzącego kolejne etapy w swoim życiu (narodziny, starzenie się, śmierć) z naturą. Równowaga jako klucz do postpastoralizmu to jeden z sześciu jego wyznaczników, na które zwrócił uwagę Terry Gifford (Fiedorczuk 2015, 92). Badacz, oprócz już wspomnianej równowagi, wymienia także: „respekt wobec świata natury" (Fiedorczuk 2015, 92), obserwację jako klucz do zrozumienia rzeczywistości, prymarną opozycję natura/kultura stanowiącą tylko koncept; konceptem jest także sama natura (Fiedorczuk 2015, 93). Korzystając z ustaleń Terrego Gifforda, autorka Cyborga w ogrodzie podaje

\footnotetext{
${ }^{4}$ Powołuję się na lakoniczną definicję ekokrytyki stworzoną przez Grega Garrarda, która zakłada, iż dziedzina ta „bada związki między literaturą a fizycznym otoczeniem człowieka”, (Tabaszewska 2015, 14; Tabaszewska 2011, 206).

${ }^{5}$ Uważam, iż ekokrytykę należy traktować jako nadrzędny nurt w stosunku do nature writing, enviromental criticism, ekopoezji, ekofeminizmu czy ekologii politycznej. Nadrzędność wspomnianego nurtu wynika $\mathrm{z}$ faktu, iż jest on szerszy znaczeniowo niż pozostałe. Pomimo tego, iż w artykule podejmuję temat zwierząt występujących w dramacie Mickiewicza, to czynię to z perspektywy ekosystemu, którego są częścią, nie sprowadzając ich do pojedynczych przykładów, jak to czyni między innymi Grzegorz Igliński (Igliński 2016).

${ }^{6}$ Korzystam z amerykańskich narzędzi badawczych, gdyż na gruncie polskim ekokrytyka dopiero rozwija się i nie została wypracowana jednolita metodologia badawcza. O tym problemie pisze między innymi Anna Barcz (Barcz 2016, 331-333).
} 
bardziej precyzyjną definicję postpastoralizmu. Julia Fiedorczuk, przeprowadzając krytykę poglądów amerykańskiego badacza na temat postpastoralizmu, dochodzi do wniosku, iż pojęcie to należy „stosować do opisu poezji, która bierze na warsztat ponowoczesny pejzaż miejski i zestawić go z elementami tradycyjnej sielanki" (Fiedorczuk 2015, 94).

XIX wiek przyczynił się do zmiany postrzegania roli człowieka w ekosystemie. Szybki rozwój nauki i techniki, któremu podporządkowana była „epoka pary i elektryczności”, sprawił, iż opozycje człowiek/przyroda, kultura/natura nabrały jeszcze wyraźniejszych rysów niż w epoce romantyzmu i stały się podstawą odmiennego postrzegania otaczającego świata (Piechota 2014; Trześniewska 2016). Niemniej jednak pierwsze dekady XIX wieku ukazywały człowieka jako element wszechświata i natury. Świat otaczający bohaterów romantycznych odpowiadał na ich problemy, komentował ich decyzje, współgrał z ich nastrojami, stawał się łącznikiem między Bogiem a człowiekiem. Problemy z wyznaczeniem przestrzeni ściśle przynależnej człowiekowi sprawiają, iż świat ludzi i przestrzeń natury przenikają się, wpływając na siebie i zacierając granice między sobą. Ludowe wyobrażenia przestrzeni sprawiają, iż zyskuje ona podmiotowość, gdyż „obdarzona jest myślą i uczuciem, na równi z człowiekiem potrafi mówić” (Trześniowski 2013, 141). Zgodnie z panteistyczną filozofią natura, ale także szerzej cały wszechświat, utożsamiane są z Bogiem. Dzięki temu każda cząstka Mickiewiczowskiego ekosystemu nie tylko nabiera znaczenia, ale również staje się równoważna w stosunku do pozostałych. Wyznawcami tego poglądu jest wielu bohaterów romantycznych, wśród nich warto wymienić chociażby Gustawa czy Kordiana, którzy przekraczają granicę między światem ludzkim a nie-ludzkim, poszukując odpowiedzi na nurtujące ich pytania dotyczące sensu własnego istnienia. Co więcej, wierzą oni, że natura przybliży ich do Boga oraz pierwotnych prawd (Janion 2007). Warto także zwrócić uwagę na fakt, iż świat otaczający Gustawa nie jest zdroworozsądkowy, dlatego też bohater, tym razem wykorzystując transcendentalizm, poznaje świat za pomocą intuicji.

Przyroda opisywana przez romantyków jest dzika i nieokiełznana, niemniej jednak jej charakterystyka jest szczegółowa. Stało się to możliwe dzięki odkryciom XVIII-wiecznych entomologów, który ukazali nieznany świat owadów, dając możliwość wprowadzenia go do literatury pięknej na szeroką skalę.

Zainteresowanie mikroświatem, a dokładniej - entomologią, pojawiło się wraz z popularyzacją dzieł Jana Swammerdama (Biblia natury z 1737 roku) czy Jeana-Henri Fabre'a ( $Z$ życia owadów, polskie wydanie 1916) (Gielata 2015, 149). Szczególną uwagę warto zwrócić na drugiego z przyrodników, który swoimi publikacjami zrewolucjonizował sposób, w jaki zaczęto patrzeć na owady. We wstępie do polskiego wydania jego dzieła przeczytać można: 
Wy ćwiartujecie zwierzę, a ja studiuję je pod szafirowym sklepieniem nieba, wy czynicie z niego przedmiot wstrętu i litości, a ja uczę je kochać. Wy badacie śmierć - ja badam życie (Fabre 1948, IX).

Obie wspomniane powyżej książki odcisnęły piętno nie tylko na entomologii jako dziedzinie, która zaczęła kształtować się w XIX wieku, ale również na literaturze, która coraz to chętniej zaczęła kierować swoją uwagę w stronę mikroświatów. Utwory romantyczne, w których owady zabierają głos, stając się wyrazicielami swoich (lub ludzkich) potrzeb, są preludium do tekstów wykorzystujących motyw przemiany człowieka w zwierzę ${ }^{7}$.

Główny bohater Dziadów cz. IV przekracza granicę między życiem a śmiercią. Egzystencja Gustawa nie kończy się wraz z jego śmiercią, po niej bohater wchodzi w kolejne stadium istnienia. Z transformacją mężczyzny koresponduje także zmiana sposobu postrzegania rzeczywistości. Polisensoryczna percepcja świata, tak charakterystyczna dla bohaterów romantycznych ${ }^{8}$, okazuje się cechą niezwykle ważną. Interesujący wydaje się fakt, iż Gustawa po śmierci łączą silniejsze więzi z naturą niż z ludźmi otaczającymi go za życia. Wspomnieć należy chociażby sytuację, w której duch Gustawa odwiedza popadający w ruinę dom rodzinny, pierwszym elementem przestrzeni przykuwającym jego uwage jest wszechobecny mech, a nie brak domowników, gdyż ich nieobecność wydaje się dla niego drugoplanową. Protagonista opisując swoje życie, unika szczegółów, starając się stworzyć ogólną, niezwykle sielankową wizję korespondującą z malowniczymi łąkami (Mickiewicz 2000, 60), zielonymi rozłogami (Mickiewicz 2000, 60), dolinami o wschodzie słońca (Mickiewicz 2000, 69) oraz lasami, po których spacerował, podziwiając florę (Mickiewicz 2000, 81). Brak uszczegółowienia ekosystemu, w którym porusza się bohater, wskazywać może na fakt, iż pomimo tego, że czuł się jego cząstką, przyjmował antropocentryczną postawę wobec otaczającego go świata. Natura w pełni podporządkowana życiu protagonisty miała wymiar czysto pragmatyczny; nie była niczym więcej jak rzeką, w której kąpał się Gustaw (Mickiewicz 2000, 80), czy błoniami, po których spacerował jako student (Mickiewicz 2000, 81). Przekroczenie bariery ziemskiej egzystencji spowodowało, iż protagonista znalazł się na granicy dwóch światów. Nowe położenie bohatera zmienia jego percepcję oglądu rzeczywistości, gdyż znajdując się „w stanie zawieszenia"9, otwiera się na nowe spojrzenie oraz na świat usytuowany daleko od antropocentryzmu.

Ciekawym i prowokującym komentarzem do Mickiewiczowskiego świata natury ukazanego w Dziadach $c z$. IV staje się pytanie zadane przez

\footnotetext{
${ }^{7}$ Mowa tutaj między innymi o Guciu zaczarowanym Z. Urbanowskiej oraz Doktorze Muchołapskim E. Majewskiego. Więcej na ten temat (Piotrowski 2014, 309-313; Piechota 2016, 327-336).

8 Warto tutaj wspomnieć o Cierpieniach młodego Wertera J.W. Goethego, Kordianie czy Balladynie J. Słowackiego.

${ }_{9}$ Rytuał dziadów, który polega na pomocy duszom w przejściu na drugą stronę, wywodzi się z przedchrześcijańskiego obrządku. Scharakteryzowane przez K. Moszyńskiego domowe demony przypominają głównego bohatera Dziadów, który tak jak i one wychodzi z ukrycia tylko po to, aby wziąć udział w dziadach, a dokładniej mówiąc, w wieczerzy wówczas odbywającej się (Moszyński 1967, 663). Problem zawieszenia duszy porusza także M. Janion, stwierdzając, że „sytuacja zawie-
} 
Zofię Stefanowską: „Czy sądzisz, że łatwiej pojąć człowieka niż małego robaczka?" (Stefanowska 1976, 60). Badaczka nieświadomie sięga po ekokrytyczne narzędzia badawcze, stwierdzając:

Można jednak pójść o krok dalej i zaryzykować twierdzenie, że między światem ludzi a światem przyrody istnieje ciągłość, jedność prawdy żywej ukrytej w pojedynczym człowieku i w małym robaczku (Stefanowska 1976, 60).

Grzegorz Igliński, korzystając z prac Stefanowskiej, ilustruje przesłanki, jakimi mógł kierować się Mickiewicz, czyniąc bohaterami Dziadów $c z$. IV owady (lub szerzej zwierzęta). Badacz wyróżnia cztery źródła motywacji, a mianowicie: motywację folklorystyczną, historyczną i światopoglądową (które to przejmuje od Stefanowskiej) (Igliński 2016, 36) oraz dodaje kolejną: aksjologiczną. Igliński stwierdza, iż obecność zwierząt rzutuje wyłącznie na świat ludzi (Igliński 2016, 37), gdyż są one są elementem gry, w której to człowiek rozdaje karty.

Charakteryzując elementy ekosystemu, w których funkcjonował bohater przed śmiercią, warto wspomnieć o rybach (karpiach i pstrągach) łowionych przez protagonistę $\mathrm{w}$ rzece. Jest to tym istotniejsze, iż są to praktycznie jedyne zwierzęta (oprócz motyla i komara) wspomniane przez niego, a funkcjonujące wokół niego za jego ziemskiego życia. Gustaw postrzega je jako część ekosystemu, w którym zarówno on, jak i pozostałe zwierzęta pełnią określone rolę. Zgodnie $\mathrm{z}$ antropocentrycznym spojrzeniem, które cechuje protagonistę, są one mu podległe, stojąc niżej w hierarchii drabiny ewolucji; ażeby sparafrazować słowa Anny Barcz, w tym wypadku ryby nie mają głosu (Barcz 2013, 106). Antropocentryczne spojrzenie na świat doczesny udowadnia, iż flora i fauna stanowią tło dla protagonisty, który tylko pobieżnie docenia „uroki przyrody”. Wrażliwy mężczyzna lubi otaczać się pięknem, nie dostrzegając jednak jego szczegółów; czyni to chociażby, przynosząc jakieś kwiateczki (Mickiewicz, 2000, 81), które traktuje instrumentalnie jako prezent dla ukochanej.

Śmierć głównego bohatera spowodowała zmianę perspektywy oglądu rzeczywistości, gdyż zaczyna on dostrzegać elementy świata, które do tej pory były poza jego percepcją; w rozmowie z księdzem stwierdza nawet:

Gdyby z twych oczu ziemskie odpadło nakrycie,

Obaczyłbyś niejedno wkoło siebie życie,

Umarłą bryłę świata pędzące do ruchu.

(Mickiewicz 2000, 98)

Gustaw zwraca również uwagę, iż dopiero po śmierci zrozumiał, że „głosu natury nie dosłyszą starzy!”, ponieważ potrzeba naiwności dziecka, żeby ją dostrzec (Mickiewicz 2000, 73). Warto przywołać słowa Jolanty Sztachelskiej, analizującej wizerunki dzieci w twórczości Prusa, która

szenia między poszczególnymi fazami życia odpowiada w micie ludowym sytuacji zatrzymania ani tu, ani tam, między społeczeństwem umarłych i żywych" (Janion 2008, 30). Jednostki, których śmierć nie została odpowiednio przypieczętowana (trzyetapowy rytuał przejścia), zyskują jednocześnie status umarlych i nieumarlych. 
zauważa, iż wywodzą się one z archetypu romantycznych postaci dziecięcych, gdyż mają ponadprzeciętne zdolności komunikowania się z przyrodą. Badaczka stwierdza nawet, iż „z przyrodą i zwierzętami żyją za pan brat, są czyste moralnie, sprawiedliwe i bohaterskie, samokrytyczne i zdolne do poświęceń” (Sztachelska 2013, 124). Mickiewicz kierując uwagę czytelnika na zmysł słuchu (dzieci zwracają się z prośbą „A posłuchajcie...” oraz pytają ojca „Tato, słyszałeś o cudzie”), w pewien sposób deprecjonuje percepcję wzrokową (Jay 1994), której to człowiek, postrzegający świat antropocentrycznie, ufa wręcz bezgranicznie, podając tym samym w wątpliwość ludzkie oceny. Dlatego też protagonista postrzegając świat polisensorycznie, szuka tajemniczego głosu natury, tak jak czyniły to dzieci, dostrzega nie tylko źdźbło trawy szumiącej na wietrze, ale również drobne stworzenia, stające się jego jedynymi pocieszycielami i kompanami:

Małego tylko ujrzał nad sobą pająka,

Z listka wisząc, u słabej kołysał się nici,

Ja i on równie słabo do świata przybici!

(...)

To mój dawny przyjaciel, czulem go powitał,

Długo z nim rozmawiałem i o wszystkom pytał:

Jak ona rano wstaje? czym się bawi z rana?

(Mickiewicz 2000, 83)

Instrumentalne ujęcie świata przyrody, które towarzyszyło bohaterowi, ustępuje miejsca dotąd niezauważalnym detalom.

W Dziadów cz. IV pojawiają się licznie motyle (ćmy jako nocne motyle), robaczki świętojańskie i kołatki, które przestają być traktowane przedmiotowo. Mimo iż owady postrzegane są jako stworzenia „kruchsze niż człowiek czy inne zwierzęta” (Żółkoś 2015, 38), ich siła może wynikać jedynie z mnogości ${ }^{10}$. Kierując się terminologią wieszcza, za motyle należy uważać także ćmy będące nośnikiem „spirytualnego sensu przyrody” (Stefanowska 1976, 49).

Równie wielkie zainteresowanie wzbudził robaczek świętojański. Stefanowska przeprowadza szczegółową analizę obrazu tego owada w kontekście Dziadów cz. IV, dowodząc między innymi, iż główny bohater prowadził rozmowę z samicą (Stefanowska 1976, 47), a „tęsknoty miłosne robaczka, sygnalizowane światłem są trwałe i niezaspokojone, do śmierci nie gasną" (Igliński 2016, 16). Niemniej jednak wspomniana badaczka nie interpretowała ekosystemu, w którym został zanurzony Mickiewiczowski bohater jako całości, traktowała go jako symbol pomagający w odczytaniu prawdy o człowieku i jego naturze:

Zamiast mówić o odkrywaniu tajemnicy przyrody, właściwiej byłoby powiedzieć o odkrywaniu tajemnicy człowieka w przyrodzie. Można wieść dialog z robaczkiem świętojańskim, jeśli mu się przypisze własne uczucia. Można odkryć duchową istotę kołatka i motyla, jeśli potraktuje się je jako ludzkie dusze (Stefanowska 1976, 58).

${ }_{10}$ Wspomina także o tym Z. Stefanowska przy okazji omawiania porównania ciem do szarańczy, nazywając to „obrazowaniem owadzim do kwadratu” (Stefanowska 1976, 50). 
Dariusz Trześniowski stwierdza, iż personifikacja natury (oraz jej poszczególnych elementów) to nie tylko „zwykły ozdobnik” literacki (Trześniowski 2013, 147). Badacz uważa, iż nowoczesne ujęcie rzeczywistości, które ma na celu odantropomorfizowanie świata, pomaga przewartościować przestrzeń, w której człowiek przestaje grać wiodącą rolę. Zabieg ten pojawia się w Dziadów cz. IV. W utworze Mickiewicza relacje człowiek - natura (rozumiane antropocentrycznie) ulegają transformacji, dzięki której otaczający Gustawa świat postrzegany jest polisensorycznie, a natura nie jest spersonifikowana i stanowi odrębny element świata.

W rzeczywistości ukazanej w pośmiertnej perspektywie warto zwrócić uwagę na kołatka, owada stojącego na pograniczu życia i śmierci, stworzenie dzielące się swoją wiedzą z ludźmi. Obecność tego niepozornego owada interesowała wielu badaczy Mickiewicza, wspomnieć należy między innymi, iż Jan Kott poświęcił mu szkic Cudowny kołatek z mickiewiczowskiego kantorka (Kott 1991, 279). Natomiast autorka Próby zdrowego rozumu nazywa go „duszą świata” (Stefanowska 1976, 58), dodając nieco później: „W najmniejszym, niedostrzegalnym robaczku odnaleźć można niepowtarzalną prawdę życia" (Stefanowska 1976, 60). Jak każdy element Mickiewiczowskiego ekosystemu, tak i kołatek pełni istotną funkcję; jest posłańcem stojącym na granicy życia i śmierci. Mickiewicz charakteryzując kołatka, nadaje mu status podmiotu, stojącego na równi z Gustawem czy Księdzem. Trafną konkluzją dla miejsca robaka w przestrzeni utworu są słowa Aleksandra Nawareckiego, który stwierdza, iż jest on

bardzo ważny, bo sytuuje się w niezwykle istotnym miejscu. Na samej granicy. Zawieszony między światem widzialnymi niewidzialnym (Stefanowska), między życiem i śmiercią (Kott), między realnością a cudownością (Ważyk) (Nawarecki 1993, 13).

Postać kołatka zwraca uwagę na unikatowość i bogactwo ekosystemu, w którym istnieje miejsce dla każdego stworzenia, także dla świdrującego oraz wiercącego się (Mickiewicz 2000, 72).

Dziadów cz. IV ukazuje człowieka dominującego nad naturą, ale jednocześnie będącego jej cząstką. Jest to szczególnie widoczne po śmierci bohatera, który szukając kontaktu ze światem, odnajduje go przez więź z przyrodą. Ukłon Mickiewicza w kierunku mikroświata sprawia, iż ekosystem zaczyna być postrzegany jako twór niezwykle bogaty, różnorodny, nieznany, ciągle otwarty na coraz to nowsze odkrycia z dziedziny entomologii. Mikrostworzenia z Dziadów cz. IV obserwują bohaterów, jednak jest to trudne do wyobrażenia sobie ze względu na dystans, jaki dzieli owady i ludzi, które z perspektywy antropologicznej stoją na dwóch przeciwległych biegunach.

Dzięki temu, iż po śmierci Gustaw postrzega świat polisensorycznie, stworzenia do tej pory marginalizowane zaczynają być eksponowane przez wieszcza, który nadaje im status bohatera, przestają być one ciekawostką traktowaną przedmiotowo w świecie ludzkim. Zabieg ten osłabia pozycję 
człowieka jako jednostki dominującej w świecie. Zaciera się również granica między przestrzenią kultury (reprezentowaną przez człowieka) a natury. Słusznie zatem zauważył Maciej Michalski, że „świat owadów stanowi właśnie dalekie rubieże naszej antropomorfizującej wyobraźni, być może nawet wyznacza jej granice, ale ich nie przekracza” (Michalski 2014, 119).

\section{Bibliografia}

Bachórz Józef, 2003, Fauna w słowniku Mickiewicza, w: Jak pachnie na Litwie Mickiewicza i inne studia o romantyzmie, Bachórz J. (red.), Gdańsk.

Bachórz Józef, 1993, O „zwierzyńcu” A. Mickiewicza (rekonesans wstępny), w: Literacka symbolika zwierząt, Martuszewska A. (red.), Gdańsk.

Barcz Anna, 2012, Przyroda - bliska czy daleka? Ekokrytyka i nowe sposoby poetyki odpowiedzialności za przyrodę w literaturze , „Anthropos?”, nr 18-19.

Barcz Anna, 2016, Realizm ekologiczny. Od ekokrytyki do zookrytyki w literaturze polskiej, Katowice.

Barcz Anna, 2013, Zwierzęta maja głos, „Teksty Drugie”, nr 1/2.

Domańska Ewa, 2013, Humanistyka ekologiczna, „Teksty Drugie”, nr 1/2.

Fabre Jean-Henri, 1948, Z życia owadów, Boguszewicz Z., Górska M. (przeł.), Warszawa.

Fiedorczuk Julia, 2015, Cyborg w ogrodzie. Wprowadzenie do ekokrytyki, Gdańsk.

Gielata Ireneusz, 2015, Nie-dostrzeżone historie - o „życiu bez ruchu”, w: Emancypacja zwierząt?, Łoch E., Trześniewska A., Piechota D. (red.), Lublin.

Igliński Grzegorz, 2016, Z Mickiewiczowskiego bestiariusza. Owady i robaki w „Dziadach”, „Wiek XIX”, nr IX(LI).

Janion Maria, 2008, Wampir. Biografia symboliczna, Gdańsk.

Jay Martin, 1994, Downcast Eyes: The Denigration of Vision Twentieth-Century French, Berkeley.

Kott Jan, 1991, Cudowny kołatek z mickiewiczowskiego kantorka, w: Pisma wybrane, t.1: Wokół literatury, Nyczek T. (wyb.), Warszawa.

Michalski Maciej, 2014, Owady i filozofia. Tischnera i Themersona wycieczki do świata insektów, „Jednak Książki”, nr 2.

Mickiewicz Adam, 2000, Dziady część IV, w: Dziady, Warszawa.

Moszyński Kazimierz, 1967, Kultura ludowa Słowian. Tom II. Kultura duchowa, Warszawa.

Nawarecki Aleksander, 1993, Mickiewicz i robaki, w: Balsam i trucizna. 13 tekstów o Mickiewiczu, Graczyk E., Majchrowski Z. (red.), Gdańsk.

Piątek Zdzisława, 1993, Przyroda i wartości, w: Wartość bycia. Władysławowi Stróżowskiemu w darze, Karłowicz D., Lipiec J., Markiewicz B. (red.), Kraków-Warszawa.

Piątek Zdzisława, 1998, Etyka środowiskowa. Nowe spojrzenie na miejsce 
człowieka w przyrodzie, Kraków.

Piechota Dariusz, 2014, Literatura drugiej połowy XIX wieku w świetle studiów nad zwierzętami (animal studies), w: Chymkowski R., Jaroszuk A. (red.), Pongo VI. Ludzie i zwierzęta, Warszawa.

Piechota Dariusz, 2016, (Nie)znane życie owadów. O mikroprzestrzeni $w$ powieści Erazma Majewskiego „Doktor Muchołapski” w: Geografia krain zmyślonych. Wokół kategorii miejsca i przestrzeni w literaturze dziecięcej, młodzieżowej i fantastycznej, Kostecka W., Skowera M. (red.), Warszawa.

Piotrowski Igor, 2014, Insektoteologia i insektoteologie. O relacjach między Bogiem, ludźmi i owadami w kulturze Zachodu (krótka introdukcja), w: Chymkowski R., Jaroszuk A. (red.), Pongo VI. Ludzie i zwierzęta, Warszawa.

Stanisławski Emil, 2015, Korzenie szowinizmu gatunkowego, w: Łoch E., Trześniewska A., Piechota D. (red.), Emancypacja zwierząt?, Lublin.

Stefanowska Zofia, 1976, Świat owadzi w IV części „Dziadów”, w: Stefanowska Z, Próba zdrowego rozumu. Studia o Mickiewiczu, Warszawa.

Sztachelska Jolanta, 2013, Narracje dziecięce Bolesława Prusa, w: Realiści, realizm, realność. W stulecie śmierci Bolesława Prusa, Paczoska E., Szleszyński B., Osiński D.M. (red.), Warszawa.

Tabaszewska Justyna, 2011, Zagrożenia czy możliwości? Ekokrytyka - rekonesans, „Teksty Drugie”, nr 3.

Tabaszewska Justyna, 2015, Zwierzęta $w$ dyskursie ekokrytycznym, w: Łoch E.,Trześniewska A., Piechota D. (red.), Emancypacja zwierząt?, Lublin.

Trześniewska Agnieszka, 2016, Ukryte życie insektów w trylogii Maurycego Maeterlicka, w: Ekomodernizmy, Trześniewska A., Piechota D. (red.), Lublin.

Trześniowski Dariusz, 2013, Realizm magiczny? O „Placówce” Bolesława Prusa, w: Realiści, realizm, realność. W stulecie śmierci Bolesława Prusa, Paczoska E., Szleszyński B., Osiński D.M. (red.), Warszawa.

Żółkoś Monika, 2015, Mikro-formy i makro-lęki. Owady jako wyzwanie dla „animal studiem”, w: Zwierzęta i ich ludzie. Zmierzch antropocentrycznego paradygmatu, Barcz A., Łagodzka D. (red.), Warszawa.

\section{O Autorce:}

Agnieszka Trześniewska - dr nauk humanistycznych, członek Laboratorium Animal Studies, współredaktorka czterotomowej serii Zielona Historia Literatury. Emancypacja zwierzat? (2015), Ekomodernizmy (2016), Między empatia a okrucieństwem (2017 w druku), Zapomniane zwierzęta (w redakcji). Autorka licznych publikacji z zakresu literatury XIX i XX wieku. 